\title{
Kadar Air dan Warna Penyedap Alami Jamur Tiram (Pleurotus Ostreatus) Berdasarkan Perlakuan Awal (Pre-treatment)
}

\author{
Ainun Nadhifah ${ }^{1}$, Yunan Kholifatuddin ${ }^{2}$, Erma Handarsari ${ }^{1 *}$ \\ ${ }^{1}$ Program Studi D3 Gizi Fakultas Ilmu Keperawatan dan Kesehatan Universitas \\ Muhammadiyah Semarang \\ ${ }^{2}$ Program Studi Teknologi Pangan Fakultas Ilmu Keperawatan dan Kesehatan Universitas \\ Muhammadiyah Semarang \\ Email*: ermahandarsari@gmail.com
}

\section{ABSTRACT}

Flavoring seasonings are food additives added with the aim of increasing flavor (palatability) and covering up deficiencies in food in terms of taste. The natural glutamate content of mushrooms has the potential to be used as a flavoring ingredient, one of which is oyster mushrooms. The quality of natural flavoring of oyster mushrooms is determined by the formula of the ingredients and the way they are produced. The drying process can affect the water content and color of seasoning.

This study aims to determine the water content and natural flavoring of oyster mushrooms based on initial treatment. This study was an experimental study using a Completely Randomized Design with 6 treatment trials (non-blanching, blanching, sodium bisulfite immersion, citric acid immersion, blanching + sodium bisulfite immersion, and blanching + citric acid immersion), and 3 test replications. The moisture content test was performed by the AOAC oven method and color analysis was measured using Konica Minolta CR-10 Color Reader. Observational data were analyzed using univariate analysis.

The results showed that the initial treatment had a tendency to increase water content. Moisture content for all samples based on pretreatment meets the quality criteria for dry products that is 10\%. The results of the color analysis showed an increase in the value of each treatment but did not show any real difference in color. The treatment using sodium bisulfite immersion and blanching showed an increase in brightness intensity and a good chroma value category compared to the control value. Based on ${ }^{\circ}$ Hue value in each treatment has the same color scheme, namely yellow - red.

Keywords: Oyster mushroom, Water Content, Color, Pre treatment, blanching

Submitted : 2021-02-03

Accepted : 2021-07-05

Published : 2021-11-08

\section{PENDAHULUAN}

Bumbu penyedap merupakan bahan tambahan pangan yang ditambahkan dengan tujuan untuk meningkatkan flavor (palatability) dan menutupi kekurangan pada makanan dalam segi rasa. Penyedap rasa yang paling dikenal adalah MSG (Monosodium Glutamat). MSG di masyarakat sering disebut Vetsin atau Micin, penyedap rasa buatan yang sudah sangat lazim digunakan sebagai bumbu masakan untuk meningkatkan cita rasa 
makanan. MSG terdiri dari komponen asam glutamate yang berikatan dengan natrium. Komponen asam glutamat inilah yang dapat memberikan rasa gurih ketika mengkonsumsi makanan yang diberi tambahan MSG (Khodjaeva et al., 2013).

Menurut Prawirohardjono, dkk. (2000) rata rata konsumsi MSG masyarakat Indonesia sekitar $600 \mathrm{mg} / \mathrm{kg}$ berat badan (BB). Menurut WHO maksimal konsumsi MSG adalah 120 mg/kg BB (Data Riset Kesehatan Dasar, 2007). Penggunaan MSG dalam jangka panjang yang sering dan berlebihan dapat mengakibatkan kerugian terhadap kesehatan seperti kerusakan otak, memacu peradangan hati, memperlambat perkembangan kecerdasan anak, kerusakan sistem syaraf dan kanker (Haq, 2015).

Ketergantungan atas pemakaian MSG pada makanan dapat diatasi dengan menggunakan penyedap rasa alami dari bahan nabati yang aman untuk dikonsumsi yaitu jamur. Jamur memiliki kandungan asam glutamat alami yang mampu berperan sebagai sumber rasa gurih yang identik dengan rasa yang dihasilkan MSG. Salah satu jenis jamur yang memiliki potensi untuk dapat diolah sebagai penyedap rasa alami yang aman yaitu jamur tiram.

Jamur tiram (Pleurotus ostreatus) adalah salah satu jamur kayu yang tidak asing bagi masyarakat Indonesia. Jamur ini mudah dibudidayakan karena memerlukan teknologi yang sederhana, dan waktu budidaya yang singkat (Kementan RI, 2011). Jamur tiram mempunyai kandungan protein 27,25 gram, karbohidrat 56,33 gram, serat 33,44 gram, dan energi 360 kkal (Tjakrokusumo, 2008).

Proses pengolahan jamur tiram sampai menjadi penyedap alami berpotensi mengakibatkan terjadinya reaksi pencoklatan (browning) akibat adanya enzim oksidase yang bertanggung jawab terhadap karakteristik warna coklat. Reaksi pencoklatan dapat dicegah dengan perlakuan awal seperti blanching, perendaman natrium bisulfit, dan perendaman asam sitrat. Pengolahan dengan perlakuan awal diharapkan mampu menginaktifasi enzim oksidase yang menyebabkan reaksi pencoklatan. Hal ini sejalan dengan penelitian yang dilakukan oleh Ardiansyah, et al (2014) yang mengungkapkan bahwa perlakuan awal sebelum pengeringan berpengaruh nyata terhadap kadar air, kadar protein, kadar abu, kadar lemak, dan kadar karbohidrat serta warna tepung jamur tiram.

Berdasarkan penelitian yang ada belum dilakukan pengaruh perlakuan awal sebelum pemasakan terhadap kadar air dan warna penyedap alami jamur tiram. Pada penelitian ini, peneliti ingin mengembangkan lebih lanjut hasil penelitian sebelumnya dengan mengkaji 
tentang pengaruh perlakuan awal terhadap kadar air dan warna penyedap alami jamur tiram berdasarkan perlakuan awal (pretreatment).

\section{METODE PENELITIAN}

\section{Bahan dan Alat}

Bahan yang digunakan dalam pembuatan penyedap alami jamur tiram menggunakan formulasi jamur tiram $62 \%$, bawang putih $4,5 \%$, bawang merah $3 \%$, garam $11 \%$, gula $9,5 \%$, maltodekstrin $10 \%$ dengan perbandingan volume air $1: 4$ (b/v). Bahan perendaman menggunakan asam sitrat $0,5 \%$ dan natrium bisulfit 2500 ppm. Alat yang digunakan yaitu alat colour reader Konica Minolta CR-10, oven dan alat-alat umum yang digunakan dalam laboratorium.

\section{Tahapan Penelitian}

Penelitian yang digunakan yaitu penelitian eksperimental dengan rancangan percobaan menggunakan Rancangan Acak Lengkap (RAL) yang terdiri dari 6 percobaan perlakuan (non blanching, blanching, perendaman natrium bisulfit, perendaman asam sitrat, blanching + perendaman natrium bisulfit, dan blanching + perendaman asam sitrat ) dengan 4 kali ulangan percobaan

Pembuatan penyedap alami jamur tiram menggunakan modifikasi dari penelitian Widyastuti dkk, 2015. Tahap pelaksanaan penelitian dimulai dengan persiapan alat dan bahan, pensortasian dan pencucian bahan, pemberian perlakuan awal pada jamur tiram, penghalusan bahan, perebusan, pengeringan, penepungan dan pengujian kadar air serta warna penyedap alami jamur tiram.

\section{Analisis Kadar Air}

Penentuan kadar air menggunakan metode oven (AOAC, 2005). Sampel serbuk penyedap alami jamur tiram ditimbang sebanyak 2 gram dan dimasukkan dalam krus yang telah dikeringkan dan diketahui bobotnya. Sampel dan krus kemudian dikeringkan dalam oven bersuhu $105^{\circ} \mathrm{C}$ selama 6 jam. Krus yang berisi sampel kemudian didinginkan dalam desikator dan ditimbang, kemudian dikeringkan kembali sampai diperoleh bobot tetap. Perhitungan Kadar Air menggunakan rumus menurut Sudarmadji, dkk, 2007:

Kadar Air $(\%)=$ $\left(\frac{(\text { Berat Awal }(g)-\text { berat akhir }(g)}{\text { Berat Awal }(g)}\right) \times 100 \%$

\section{Analisis Warna}

Analisa warna penyedap alami jamur tiram diukur dengan menggunakan Colour Reader Konica Minolta CR-10. Alat ini menggunakan sistem warna L, a dan b. Nilai L menyatakan kecerahan yang menunjukkan warna akromatik putih, abuabu dan hitam. Nilai a menyatakan warna 
kromatik campuran merah - hijau. Nilai b menyatakan warna kromatik campuran kuning dan biru.

Pengujian warna dilakukan dengan meletakkan sampel penyedap alami jamur tiram diatas kertas putih kemudian diukur dan diulang sebanyak tiga kali pada setiap sampelnya, setelah itu dianalisis warna berdasarkan nilai $L$ dan nilai a, b menjadi HUE ( ${ }^{\circ}$ hue) dan nilai chroma (C) dapat dilakukan dengan rumus :

$$
\begin{aligned}
\text { HUE } & =\tan ^{-1}(\mathrm{a} / \mathrm{b}) \\
\text { Chroma } & =\left(\left(\mathrm{a}^{2}\right)+\left(\mathrm{b}^{2}\right)\right)^{1 / 2}
\end{aligned}
$$

\section{Analisis Data}

Data yang diperoleh kemudian dianalisis menggunakan analisis univariat. Hasil yang didapatkan dimasukkan ke dalam tabel frekuensi dan disajikan secara diskriptif.

\section{HASIL DAN PEMBAHASAN}

\section{Kadar Air}

Pengujian kadar air bertujuan untuk mengetahui apakah ada kecenderungan perlakuan awal (pre-treatment) terhadap kadar air penyedap alami jamur tiram. Hasil analisis kadar air penyedap alami jamur tiram ditunjukkan pada gambar 1.

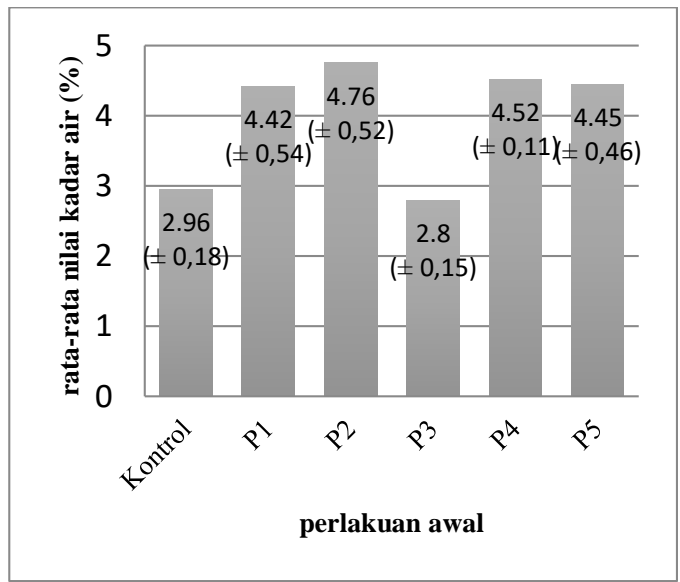

Gambar 1. Kadar Air Penyedap Alami Jamur Tiram (P1: blanching; P2: perendaman natrium bisulfit, P3: perendaman asam sitrat, P4: blanching + perendaman natrium bisulfit, P5: blanching + perendaman asam sitrat)

Berdasarkan gambar 1 menunjukkan bahwa pada penyedap alami jamur tiram dengan perlakuan blanching, Perendaman natrium bisulfit, blanching + Perendaman natrium bisulfit dan blanching + Perendaman asam sitrat menunjukkan kadar air yang berbeda nyata dengan penyedap alami tanpa perlakuan awal (kontrol). Penyedap alami jamur tiram yang memiliki kadar air mendekati kontrol adalah penyedap alami berdasarkan perlakuan perendaman asam sitrat yaitu $2.8 \%$.

Kadar air penyedap alami jamur tiram dengan perlakuan P2 (perendaman dengan natrium bisulfit) memiliki kadar air paling tinggi yaitu $4.76 \%$. Hal ini sesui dengan pernyataan Ardiansyah, et al (2014) menyatakan bahwa natrium bisulfit merupakan senyawa garam, garam akan menarik cairan dalam bahan dan menyebabkan penyusutan volume yang lebih besar. Kondisi tersebut menyebabkan penguapan air terhambat. Kadar air 
terendah didapat dari perlakuan perendaman asam sitrat. Asam sitrat dapat menyebabkan ikatan hidrogen dalam pati melemah sehingga air tidak mudah terikat (Asasia, dkk, 2018).

Kandungan air dalam bahan makanan ikut mempengaruhi tekstur, penampakan, dan cita rasa makanan. Kadar air juga sangat berpengaruh terhadap mutu bahan pangan karena mampu mempengaruhi sifat fisik, kimia, perubahan mikrobiologi dan perubahan enzimatis. Winarno (1997) menyatakan bahwa produk pangan dengan kadar air kurang $14 \%$ cukup aman untuk mencegah pertumbuhan kapang. Syarat mutu SNI belum ada kriteria kadar air penyedap rasa alami dari jamur yang distandarkan. Namun berdasar SNI 01-4273-1996 tentang syarat mutu penyedap rasa sapi yaitu maksimal 4\%. Apabila dibanding dengan penyedap rasa sapi, yang memenuhi syarat adalah kontrol dan P3.

\section{Warna}

Warna merupakan salah satu faktor penting yang menentukan tingkat penerimaan konsumen terhadap suatu produk salah satunya adalah penyedap alami jamur tiram. Analisis warna dilakukan untuk mengetahui kecerahan penyedap alami jamur tiram menggunakan parameter L dan skema warna penyedap alami jamur tiram berdasarkan parameter a dan b yang akan menghasilkan kromatisisasi warna yang dilihat dari hasil perhitungan nilai chroma dan hue sehingga dapat menunjukkan warna sempel, cerah dan terang atau gelapnya produk. Warna produk penyedap alami jamur tiram dapat dilihat pada gambar 2 sebagai berikut:

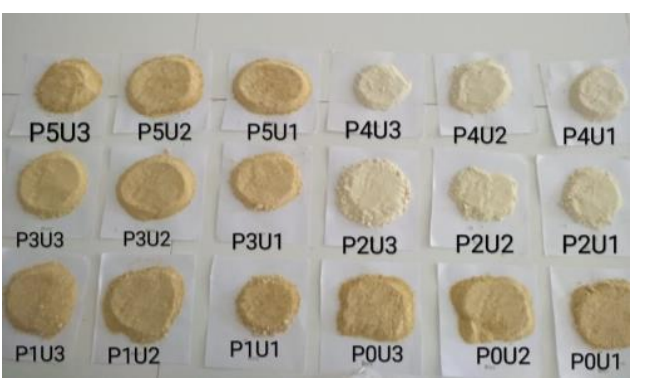

Gambar 2. Produk Penyedap Alami Jamur

Tiram

\section{Kecerahan warna $(\mathrm{L})$}

Hasil uji warna menunjukkan bahwa perlakuan awal (pre-treatment) memiliki kecenderungan terhadap kecerahan penyedap alami jamur tiram. Hal tersebut dapat dilihat pada gambar 3 sebagai berikut:

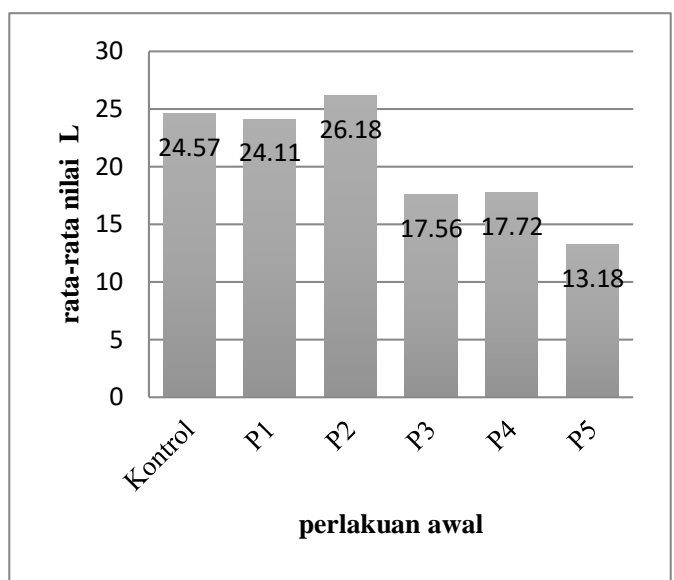

Gambar 3. Rata-rata nilai L Penyedap Alami Jamur Tiram ((P1: blanching; P2: perendaman natrium bisulfit, P3: perendaman asam sitrat, P4: blanching + perendaman natrium bisulfit, P5: blanching + perendaman asam sitrat)

Berdasarkan gambar 4.2 dapat diketahui bahwa pada perlakuan P1 
(blanching) menghasilkan kecerahan mendekati nilai kecerahan tanpa perlakuan awal (kontrol) dengan nilai kecerahan 24,11. Pada perlakuan P3, P4 dan P5 menunjukkan nilai kecerahan kurang dari kontrol dengan nilai kecerahan terendah didapat dari perlakuan blanching + perendaman asam sitrat yaitu 13,18 dan perlakuan P2 (perendaman natrium bisulfit) memiliki kecerahan paling tinggi yaitu 26,18 . Hal ini menunjukkan bahwa perlakuan dengan natrium bisulfit mampu mencegah reaksi pencoklatan.

Pencoklatan secara enzimatis terjadi karena adanya reaksi antara substrat dengan $\mathrm{O}_{2}$ yang dikatalis oleh enzim fenolase yang terdapat dalam jamur tiram. Menurut Ardiansyah, et al (2014) natrium bisulfit mampu mencegah reaksi pencoklatan secara enzimatis karena glukosa akan membentuk $\alpha$ hidroksisulfonat, dimana sulfit bereaksi dengan gugus aldehid atau keton sehingga reaksi antara gula reduksi dengan asam amino tidak terjadi.

Hal ini sejalan dengan penelitian yang dilakukan oleh Mustamin (2014) natrium bisulfit merupakan suatu garam yang pada konsentrasi tertentu dapat memutihkan bahan makanan sehingga dapat meningkatkan nilai kecerahan pada suatu produk.

\section{Nilai Chroma}

Chroma merupakan tingkatan warna berdasarkan ketajamannya yang berfungsi untuk mendefinisikan warna suatu produk cenderung mengkilap atau kusam. Warna produk penyedap alami jamur tiram berdasarkan analisis nilai chroma dapat dilihat pada gambar 4 sebagai berikut :

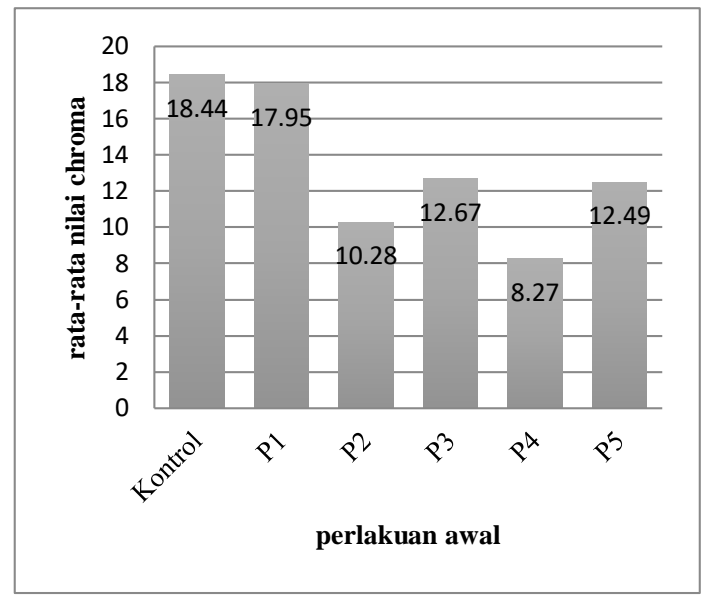

Gambar 4. Rata-rata Nilai Chroma Penyedap Alami Jamur Tiram ((P1: blanching; P2: perendaman natrium bisulfit, $\mathrm{P3}$ : perendaman asam sitrat, P4: blanching + perendaman natrium bisulfit, P5: blanching + perendaman asam sitrat)

Menurut Ramdani, et al (2019) mutu produk berdasarkan nilai chroma diklasifikasikan berdasarkan kategori warna yaitu sangat baik (>20), baik sekali (17 - 20), baik (14 - 17) dan kurang baik (<14). Pada gambar 4.3 dapat dilihat bahwa nilai chroma pada perlakuan perendaman natrium bisulfit, perendaman asam sitrat, blanching + perendaman natrium bisulfit dan blanching + perendaman asam sitrat memiliki warna kurang baik dengan nilai chroma 10,28, 12,67, 8,27 dan 12,49. Penerapan perlakuan blanching pada 
penelitian ini menghasilkan nilai chroma 17,95 tidak berbeda nyata dengan nilai chroma tanpa perlakuan awal (kontrol) yang menghasilkan warna baik yaitu 18,44.

Nilai chroma penyedap alami jamur tiram pada penelitian ini paling baik terdapat pada perlakuan kontrol. Hal ini sejalan dengan penelitian yang dilakukan oleh Ardiansyah, et al (2014) pada perlakuan kontrol tidak melibatkan proses perendaman yang menyebabkan penyerapan air sehingga pada awal proses pengeringan terjadi penyusutan volume lebih besar dan menyebabkan intensitas warna coklat lebih meningkat.

\section{Nilai ${ }^{\circ} \mathrm{Hue}$}

Nilai hue merupakan karakteristik warna berdasarkan cahaya yang dipantulkan oleh objek yang merupakan nilai keseluruhan yang didominasi pada suatu produk atau warna utama suatu produk. Warna produk penyedap alami jamur tiram berdasarkan analisis nilai hue seperti ditunjukan pada gambar 5.

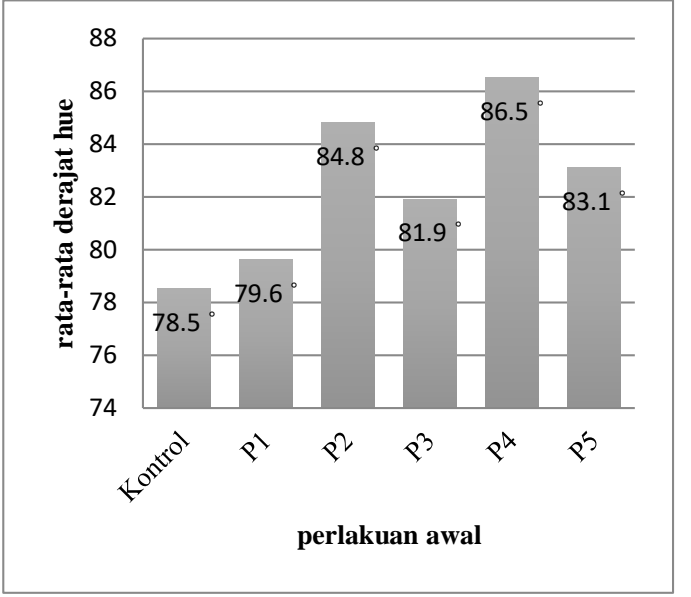

Gambar 4.5. Rata-rata Nilai Hue Penyedap Alami Jamur Tiram(P1: blanching; P2: perendaman natrium bisulfit, $\mathbf{P 3}$ : perendaman asam sitrat, P4: blanching + perendaman natrium bisulfit, P5: blanching + perendaman asam sitrat)

Berdasarkan gambar 5 menunjukkan bahwa penyedap alami jamur tiram dengan perlakuan awal (pre-treatment) memiliki skema warna yang sama yaitu kuning merah. Hasil rata-rata derajat hue tertinggi dapat diperoleh dari perlakuan blanching + perendaman natrium bisulfit yaitu $86.5^{\circ}$ sedangkan dengan tanpa perlakuan memiliki rata-rata terendah yaitu $78.5^{\circ}$.

Warna penyedap alami jamur tiram pada penelitian berwarna kuning sampai coklat dan warna pada jamur tiram sebelum dilakukan pengeringan berwarna putih kekuningan. Warna kuning pada penyedap alami jamur tiram dapat disebabkan terjadinya reaksi maillard antara gula pereduksi dengan asam amino yang dapat menghasilkan warna kecoklatan (Winarno,1992). Reaksi maillard menghasilkan bahan berwarna coklat yang disebut melanoidin. Oleh sebab itu 
perlakuan awal (pre-treatment) tidak memiliki pengaruh nyata terhadap warna berdasarkan nilai derajat hue.

\section{KESIMPULAN}

Berdasarkan hasil penelitian yang telah dilakukan dapat disimpulkan bahwa :

1. Perlakuan awal (pre-treatment) pada penyedap alami jamur tiram memiliki kecenderungan untuk meningkatkan kadar air. Kadar air cenderung mengalami peningkatan pada semua perlakuan kecuali perlakuan dengan perendaman asam sitrat. Kadar air untuk semua sampel berdasarkan perlakuan awal memenuhi kriteria mutu pada produk kering yaitu $10 \%$.

2. Perlakuan awal (pre-treatment) pada penyedap alami jamur tiram menunjukkan adanya peningkatan nilai pada setiap perlakuan namun tidak menunjukkan perbedaan nyata pada warna. Perlakuan dengan menggunakan perendaman natrium bisulfit dan blanching menunjukkan adanya peningkatan intensitas kecerahan serta kategori nilai chroma yang baik dibandingkan dengan nilai kontrol. Nilai ${ }^{\mathrm{O}}$ Hue pada setiap perlakuan memiliki skema warna yang sama yaitu kuning - merah.

\section{DAFTAR PUSTAKA}

AOAC., 2005. Official method of analysis of the association of official analytical of chemist. Arlington, Virginia, USA: Published by The Association of Official Analitycal Chemist, Inc.

Ardiansyah, Nurainy, F., dan Astuti, S. 2014. Pengaruh perlakuan awal terhadap karakteristik kimia dan organoleptik tepung jamur tiram (Pleurotus ostreatus). Jurnal Teknologi Industri dan Hasil Pertanian, 19 (2): 117-126.

Asasia, A. A. P dan Sudarminto, S. Y. 2018. Pengaruh Konsentrasi Tepung Maizena dan Konsentrasi Asam Sitrat. Jurnal Pangan dan Agroindustri. Vol. 6. No. 1: $64-74$.

Haq, N.D. 2015. Sepuluh Efek Bahaya MSG Bagi Kesehatan Jangka Panjang. Makalah. Fakultas Ilmu Keperawatan dan Kesehatan Universitas Muhammadiyah Semarang.

Kementan RI, 2011. Pedoman Teknologi Penanganan Pascapanen Jamur (Jakarta: Kementan RI, 2011).

Khodjaeva, U., T. Bojnanská, V. Vietoris, O. Sytar \& R. Singh. (2013). Food Additives as Important Part of Functional Food. International Research Journal of Biological Sciences, 2(4):74-86.

Mustamin, 2014, Efektifitas konsentrasi natrium bisulfit dan lama blanching terhadap parameter kualitas tepung jambu mete, Jurnal Agribisnis Perikanan, UNKHAIR 
Praptiningsih, Y. and Palupi, N. W. 2014. Characterization of functional properties of oxidized tapioca and sodium alginate. Proceeding of International Seminar ISOSTECH, pp: 99-102.

Prawirohardjono W., Dwiprahasto., I Astuti., Indwiani, S. Hadiwandowo.2000. The administration to Indonesians of monosodium L-glutamate in Indonesian foods: An assessment of Adverse Reactions in a Randomized Double-Blind, Crossover, Placebo Controlled Study. J. Nutrition 130, 1074S-1076S

SNI 014273, 1996. Penyedap Rasa Sapi. Badan Standarisasi Nasional. Jakarta

Sudarmadji S., Haryono. B.,Suhardi. 2007. Prosedur Analisa untuk Bahan
Makanan dan Pertanian. Liberty. Yogyakarta.

Tjokrokusumo, D. 2008. Jamur Tiram (Pleurotus ostreatus) Untuk Meningkatkan Ketahanan Pangan dan Rehibilitasi Lingkungan. JRL, 4(1): 53-62.

Widyastuti, N., Donawati, T., dan Reni, G. 2015. Potensi Beberapa Jamur Basidiamycota Sebagai Penyedap Alternatif Masa Depan. Prosiding Seminra Agroidastri dan Lokakarya Nasional FKPT - TPI Program Studi TPI - UTM.

Winarno, F. G (1992). Pangan : Gizi Teknologi dan Konsumsi. Gramedia Pustaka Utama: Jakarta. 